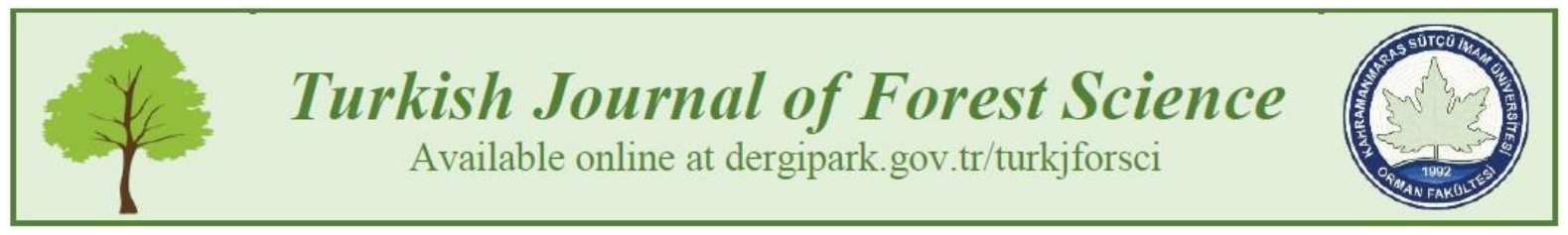

\title{
DOĞU AKDENİZ BÖLGESINNDEKİ RELİKT KIZILAĞAÇ (Alnus glutinosa (L.) Gaertn.) POPÜLASYONLARININ TOHUM ÖZELLIKLERİ
}

\author{
Tülin YILMAZ ${ }^{1}$, Mustafa YILMAZ ${ }^{2 *}$ \\ ${ }^{1}$ Malatya Orman İșletme Müdürlüğ̈̈, Malatya \\ ${ }^{2}$ Bursa Teknik Üniversitesi, Orman Fakültesi, Bursa \\ "Sorumlu yazar: mustafa.yilmaz@btu.edu.tr
}

Tülin YILMAZ: https://orcid.org/0000-0002-1771-5788

Mustafa YILMAZ: https://orcid.org/0000-0002-0855-2032

Please cite this article as: Yılmaz, T. \& Yılmaz, M. (2021) Doğu Akdeniz Bölgesindeki relikt kızılağaç (Alnus glutinosa (L.) Gaertn.) popülasyonlarının tohum özellikleri, Turkish Journal of Forest Science, 5(1), 150-164.

\section{ESER BILGISI / ARTICLE INFO}

Araştırma Makalesi / Research Article

Geliş 5 Şubat 2021 / Received 5 February 2021

Düzeltmelerin gelişi 8 Nisan 2021 / Received in revised form 8 April 2021

Kabul 16 Nisan 2021 / Accepted 16 April 2021

Yayımlanma 30 Nisan 2021 / Published online 30 April 2021

ÖZET: Bu çalışmada, Doğu Akdeniz bölgesinde bulunan kızılağaç (Alnus glutinosa (L). Gaertn)'ın relikt popülasyonlarının tohum özellikleri araştırılmıştır. Kahramanmaraş, Osmaniye ve Adana illerinde 6 relikt popülasyondan (Suçatı, Türkoğlu, Andırın, Düziçi, Kozan, Karaisalı) 2012 ve 2013 yıllarında kozalak temin edilmiştir. Laboratuvarda kozalakların morfolojik özellikleri ve bu kozalaklardan elde edilen tohumların 1000-dane ağırlıkları, morfolojik özellikleri, doluluk oranları, çimlenme yüzdeleri, çimlenme hızları ile yıllar arası farklılıklar araştırılmıştır. Tohumlar 0, 2, 4, 6, 8 hafta katlama işlemi sonrasında $24^{\circ} \mathrm{C}$ 'de çimlenme testine alınmıştır. Ayrıca, doğal popülasyonlarda da gözlemler yapılmıştır. Ortalama kozalak boyu $17.89 \mathrm{~mm}$, çap1 $9.95 \mathrm{~mm}$, ağırlığ $0.49 \mathrm{gr}$; ortalama tohum boyu 2.64 $\mathrm{mm}$, eni $2.31 \mathrm{~mm}$, kalınlığ $0.73 \mathrm{~mm}$ olarak ölçülmüştür. Genel ortalama dolu tohum oranı \%42.0 olarak bulunmuştur. Ortalama 1000-dane ağırlığı 1.24 gr olarak belirlenmiştir. En yüksek çimlenme yüzdesi (\%64.0) Kozan popülasyonunde elde edilmiştir. Ortalama çimlenme yüzdesi \%26.7, ortalama çimlenme hızı 4.1 gündür. Genel olarak tohumlardaki derin olmayan dormansinin giderilmesi için 2 ile 4 haftalık katlama işlemi yeterli olmuştur.

Anahtar kelimeler: Kızılağaç, Alnus glutinosa, Tohum, Çimlenme, Relikt popülasyon

\section{RESEARCHES ON THE SEED CHARACTERISTICS OF RELICT COMMON ALDER (Alnus glutinosa (L.) Gaertn.) POPULATIONS IN THE EASTERN MEDITERRANEAN REGION}

\footnotetext{
ABSTRACT: In this study, seed characteristics of Common alder (Alnus glutinosa (L).Gaertn.) relict populations in the Eastern Mediterranean Region were investigated. The cones of the species were collected from six different relict populations (Sucati, Turkoglu,
} 
Andirin, Düziçi, Kozan, Karaisalı) in Kahramanmaraş, Osmaniye, and Adana provinces in both 2012 and 2013. In the laboratory, the morphological characteristics of cones and seeds, percentage of sound seeds, and 1000-seed weight were researched. Dormancy existence and depth, germination percentages, germination speed, and the differences between the years (2012 and 2013) were also determined. The seeds were taken to germination tests after 0,2, $4,6,8$ weeks of prechilling at $24^{\circ} \mathrm{C}$. The relict populations in the region were also observed in terms of development, regeneration, and sustainability. Average cone length, cone diameter, cone weight, seed lentgth, seed width, and seed thickness were $17.89 \mathrm{~mm}, 9.95$ $\mathrm{mm}, 0.49 \mathrm{~g}, 2.64 \mathrm{~mm}, 2.31 \mathrm{~mm}$, and $0.73 \mathrm{~mm}$, respectively. Overall average sound seed percentage was found to be $42.4 \%$. Average 1000 -seed weight of six populations was $1.24 \mathrm{~g}$. The highest germination percentage $(64.0 \%)$ was obtained in Kozan provenance. The average germination percentages and mean germination times of populations in both years were $26.7 \%$ and 4.1 days, respectively. In general, about 2 or 4 weeks of prechilling was sufficient to eliminate the nondeep seed dormancy

Keywords: Black Alder, Alnus glutinosa, Seed, Germination, Relict population

\section{GíRiş}

Kızılağaç (Alnus glutinosa (L.) Gaertn.) ülkemizdeki doğal odunsu türlerden biridir. Tür 2030 m'ye kadar boy yapabilen, esmer kabuklu, seyrek dallı bir ağaçtır. Dünya üzerinde geniş bir yayılışa sahip olan A. glutinosa Türkiye'den başka tüm Avrupa, İran'ın kuzeyi, Kafkasya, ve Kuzeybatı Afrika'da yayılış göstermektedir (Yaltırık, 2000; More \& White, 2002). A. glutinosa genel olarak Türkiye'nin kuzeyinde yer alır. Ayrıca Doğu kayını (Yılmaz, 2010) ve yalankoz (Yılmaz, 2014) gibi türün ana yayılışından çok uzakta Güney Anadolu'da da relikt popülasyonları bulunmaktadır.

Doğu Akdeniz bölgesindeki kızılağaçların yayılışı dere kenarlarında olup kesintilidir. $\mathrm{Bu}$ dağınık yayılışa bağlı olarak türün bölgede değişik isimleri ortaya çıkmıştır. Kızılağaç, Osmaniye yöresinde "Karacaağaç veya Karacan" olarak adlandırılmakta ve odunundan topaç ve sandık yapılmaktadır. Gövde ve kabukları tuzlu suda kaynatılarak boya yapımında değerlendirilmektedir (Özer, 2006). Kızıl renginden dolayı parke ve dekoratif süs eşyası yapımında faydalanılmaktadır. Kuvvetli kütük sürgünü verme özelliğinden dolayı (Kajba and Gracan, 2003) yer yer yakacak odun olarak da kullanılmaktadır.

Kızılağaçlar genellikle hızlı gelişen türlerdir (Evans, 1984; Funk, 1990). A. glutinosa ilk yıllardan itibaren hızlı büyümekte ve $30 \mathrm{~m}$ boya kadar ulaşabilmektedir. Hızlı gelişme özelliklerinden dolayı, Alnus glutinosa ve Alnus rubra enerji elde etmek üzere biyokütle verimi için değerlendirilmektedir (Gillespie \& Pope, 1994). Türün hızlı büyüme özelliği araştırma yapılan sahalarda da dikkati çekmektedir.

A. glutinosa genellikle dağların korunaklı derin vadilerinde, kumlu topraklarda ve çakıllı nemli göl kıyıları ile nehir yataklarında bulunur (Savill, 1991). Verimsiz ve kuru yerlerde kısa ömürlüdür. Türün Doğu Akdeniz Bölgesi'ndeki relikt yayılışları dere kenarlarında suya en yakın dar şeritte bulunmakta olup suya bağımlıdırlar. Zarar görmediği doğal alanlarda derenin suyundan yararlanarak dereyi gölgelemektedirler (Şekil 1). Kızılağaçlar dere ve akarsu kenarlarında çınar (Platanus orientalis), söğüt (Salix spp.), kızılcık (Cornus mas), fındık (Corylus) ve doğu kayını (Fagus orientalis) gibi diğer dere dostu ağaçlarla beraber yer alır. 
Kızılağaçlar; kök nodülleri ve mikroorganizmalar sayesinde atmosferdeki azotu bağlayarak toprak verimliliğini arttırır (Tarrant \& Trappe, 1971; Benson \& Sylvester, 1993; Y1lmaz \& Ekici, 2011; Y1lmaz \& Aslan, 2013; Y1lmaz, 2020). Bu özellikleriyle nemli habitatlarda mineralce fakir topraklardaki bitkilendirmelerde değerlendirilmektedirler (Harrington, 2006). Kızılağaçlar genellikle her yıl yeterince tohum vermektedir. A. glutinosa, tohum verimi ve doluluk bakımından yıldan yıla önemli farklılıklar gösterebilmektedir (McVean, 1956). Tohumları hafiftir ve rüzgarlarla, su akıntıları ve hayvanlarla uzak mesafelere taşınırlar (Harrington, 2006). Türün tohumları yıl boyu suda kalabilmekte ve canlılığını koruyabilmektedir (McVean, 1956). Kızılağaç tohumları bazı kuş türleri için de önemli bir besin kaynağıdır (White \& West, 1977).
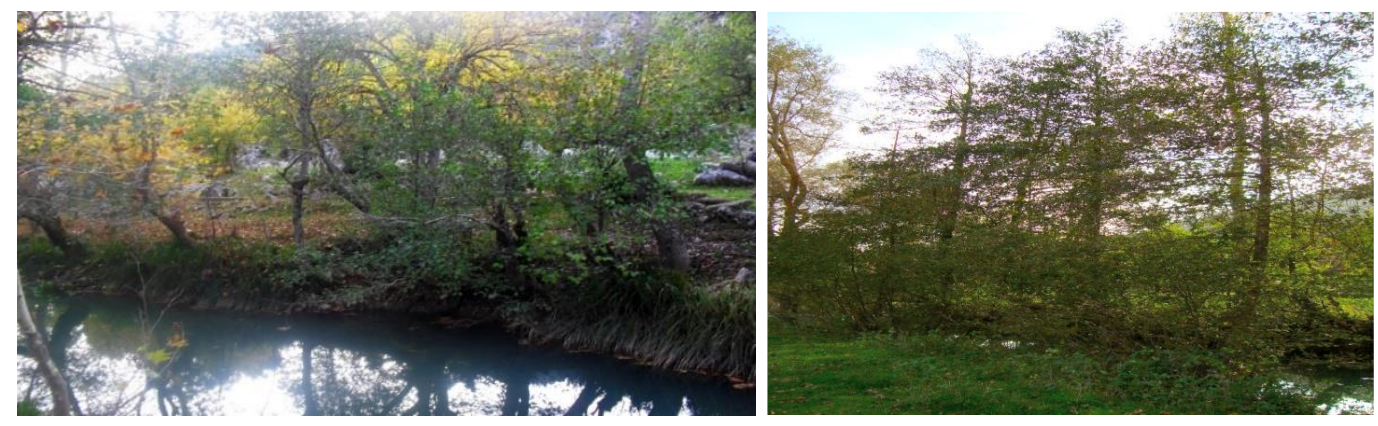

Şekil 1. A. glutinosa'nın dere kenarındaki doğal popülasyonları (Andırın)

Kızılağaçlarda dormansi derinliği türler arasında, tür içinde ve popülasyonlara göre değişebilmektedir (Baskin \& Baskin, 2014; Y1lmaz, 2020). Alnus rhombifolia ve Alnus incana ssp. tenufolia'nın taze tohumlarının çimlenme yüzdesinin (katlamalı ve katlaması) dolu tohum oranına göre yeterli olduğu tespit edilmiştir (Harrington vd., 2008). Alnus glutinosa ve A. incana türünün taze tohumları katlamasız olarak çimlenmiş, fakat tohumların kurutulması durumunda dormansi belirlenmiştir (Schalin, 1967). Bununla birlikte, kızılağaç tohumlarındaki dormansi $+5{ }^{\circ} \mathrm{C}$ 'de soğuk-1slak katlamayla giderilebilmektedir (Baskin and Baskin, 2014).

Kızılağaç tohumları hafiftir, boş tohumları uzaklaştırmak ve ayırmak zordur (Ager vd., 1994). Dolu tohum sayısının en yüksek olduğu yer ağacın tepe tacıdır (Brown, 1986). Kozalakların rengi olgunluk için iyi bir göstergedir. A. rubra' da olgun kozalaklar sarı, gri veya kahverengi tonlarında alacalı olmasına karşın olgunlaşmamış kozalaklar yeşildir (Hibbs \& Ager, 1989).

Kızılağaç popülasyonları arasında önemli coğrafi varyasyonlar mevcuttur (Ager \& Stettler, 1994; Dang vd., 1994). Relikt popülasyonlar morfolojik ve fizyolojik nitelikler bakımından ana yayılışlardan farklılaşabilmektedir (Yılmaz vd., 2013; Kuşçuoğlu \& Yılmaz, 2020). Bu relikt popülasyonların devamı ve araştırılmasında en önemli yollarından biri de tohum çalışmalarıdır (Moreno-Saiz vd., 2003; Yılmaz, 2015; Yılmaz, 2020).

$\mathrm{Bu}$ çalışmada Doğu Akdeniz bölgesindeki relikt kızılağaç gen kaynaklarının tohum özellikleri araştırılmıştır. Bu amaçla iki farklı yılda (2012 ve 2013) ve 6 değişik popülasyondan (Suçatı, Türkoğlu, Andırın, Düziçi, Kozan, Karaisalı) kozalak toplanmıştır. Kozalak ve kozalaklardan çıkarılan tohumların morfolojik özellikleri ölçülmüştür. Tohumlardaki dormansinin varlığ 1 ve derinliği ile çimlenme nitelikleri belirlenmiştir. 


\section{MATERYAL VE YÖNTEM}

\section{Araştırmada kullanılan tohum materyali}

$\mathrm{Bu}$ çalışmada kullanılan tohum materyali Kahramanmaraş, Osmaniye ve Adana illerinde Suçatı, Türkoğlu, Andırın, Düziçi, Kozan, Karaisalı popülasyonlarından elde edilmiştir (Tablo 1). Bu 6 popülasyona ait kozalak ve tohumlar A. glutinosa'nın Doğu Akdeniz'de doğal olarak yayılış gösterdiği popülasyonlardan (Şekil 2) temin edilmiştir. Bölgede olduğu kaydedilen (Aksoy, 2018) yapraklarının her iki yüzeyi de boz renkli tüylerle kaplı ve kısa boylu A. glutinosa subsp. antitaurica alttürü belirgin olmadığından, bu çalışmada bütün popülasyonlar A. glutinosa olarak kabul edilmiştir. Popülasyonların seçiminde birbirine olan mesafe dikkate alınmıştır.

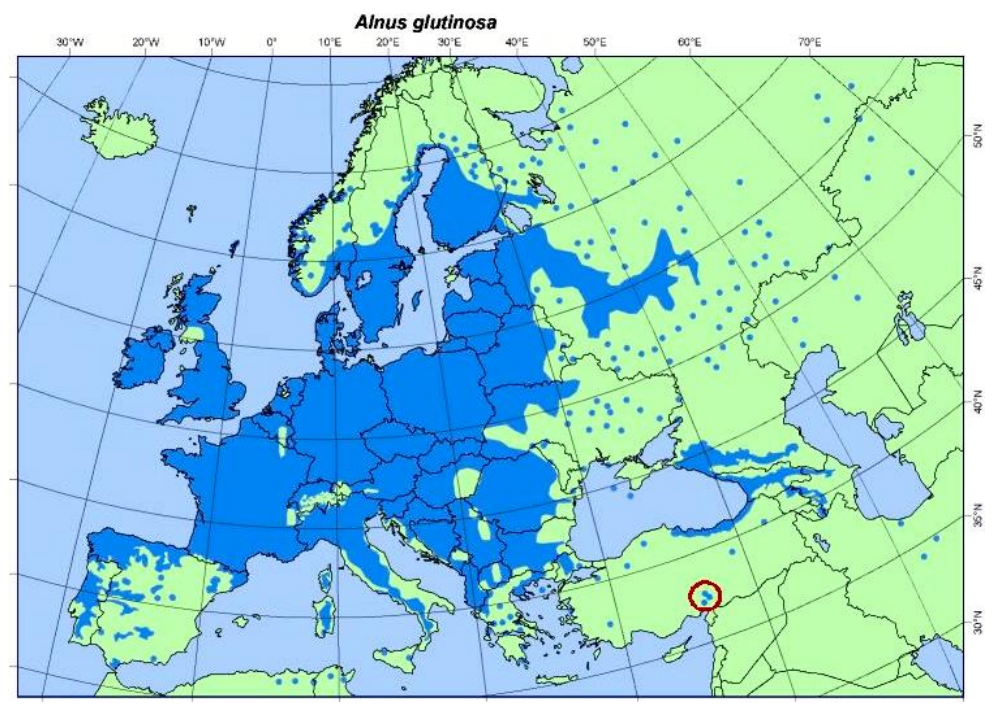

Şekil 2. A. glutinosa'nın doğal yayılışı ve tohum toplanan relikt popülasyonlar (Euforgen, 2021).

Tablo 1. Araştırmada kullanılan tohum materyaline ait bilgiler

\begin{tabular}{lccccc}
\hline Popülasyon & Enlem & Boylam & Yükselti $(\mathrm{m})$ & 2012 Y1lı Top. Tar. & 2013 Y1l Top. Tar. \\
\hline Suçatı & $37^{\circ} 45^{\prime}$ & $36^{\circ} 40^{\prime}$ & 728 & 27.10 .2012 & 10.11 .2013 \\
Türkoğlu & $37^{\circ} 18^{\prime}$ & $36^{\circ} 40^{\prime}$ & 1110 & 24.10 .2012 & 14.11 .2013 \\
Andırın & $37^{\circ} 38^{\prime}$ & $36^{\circ} 20^{\prime}$ & 1121 & 05.11 .2012 & 19.11 .2013 \\
Düziçi & $37^{\circ} 16^{\prime}$ & $36^{\circ} 29^{\prime}$ & 747 & 02.11 .2012 & 06.11 .2013 \\
Kozan & $37^{\circ} 29^{\prime}$ & $35^{\circ} 48^{\prime}$ & 164 & 06.11 .2012 & 05.11 .2013 \\
Karaisalı & $37^{\circ} 24^{\prime}$ & $35^{\circ} 16^{\prime}$ & 697 & 03.11 .2012 & 05.11 .2013 \\
\hline
\end{tabular}

\section{Kozalakların toplanması ve tohumların çıkartılması}

Her bir popülasyonda en az 10 ağaçtan yaklaşık 4-5 kg kozalak toplanmış ve bez torba içinde laboratuvara getirilmiştir. Kozalaklar laboratuvarda kâğıt üzerine tek kat serilerek hava sirkülasyonu altında kurutulmuştur. Kuruyan kozalaklardan tohumlar 2-3 hafta içinde dökülmüştür (Şekil 3). Kozalak üzerindeki yapışkan madde sebebiyle tohumu dökülmeyen kozalaklar ise elle açılmıştır. Kozalaklardan çıkan tohumlar tezgâh üzerine serilerek kurutulmuştur. Hava kurusu duruma gelen tohumlar hem üzerindeki yapışkan maddeyi uzaklaştırmak, hem de oluşabilecek mantar zararından korumak amacıyla 10 dakika \%2'lik sodyum hipoklorit çözeltisi içinde bekletilmiştir. Daha sonra yıkanıp kurutularak $4 \pm 1{ }^{\circ} \mathrm{C}$ 'de buzdolabında plastik kaplarda saklamaya alınmıştır. 

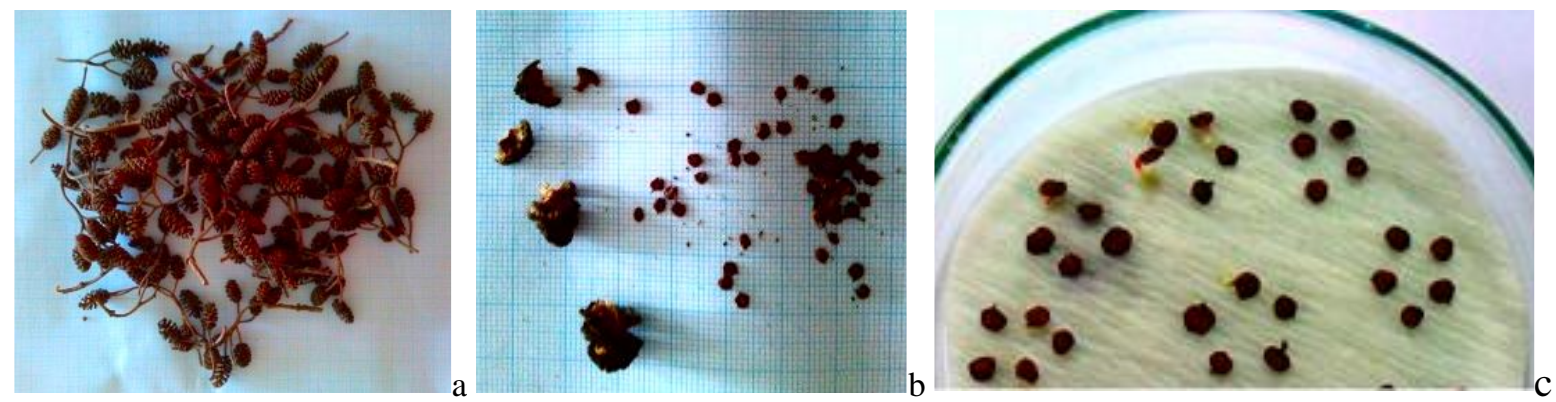

Şekil.3. Relikt A. glutinosa kozalakları (a), kozalaktan çıkarılan tohumlar (b) ve çimlenen bazı tohumları (c)

\section{Katlama işlemi ve çimlenme testleri}

Tohum dormansisini gidermek amacıyla tohumlara çıplak katlama işlemi uygulanmıştır. Çıplak soğuk katlama işlemi $11 \mathrm{~cm}$ çapındaki Petri kapları içerisinde iki kat filtre kâğıdı üzerinde buzdolabında $\left(4 \pm 1^{\circ} \mathrm{C}\right)$ gerçekleştirilmiştir (Yılmaz, 2005). Test süresince filtre kâğıtlarının sabit nemde kalabilmesi için distile_su kullanılmıştır. 2012 yılında toplanan tohumlar 0 (katlamasız), 2, 4, 6, 8 hafta katlama işleminden sonra çimlenme testine alınmıştır. 2013 yılında toplanan tohumlar ise ilk sonuçlar dikkate alınarak sadece 0, 2, 4 hafta katlama işleminden sonra çimlenmeye alınmıştır.

Çalışmada çimlenme testleri $11 \mathrm{~cm}$ çapındaki Petri kapları içinde iki kat filtre kâğıtları üzerinde $24^{\circ} \mathrm{C}$ 'de gerçekleştirilmiştir. Testler $150(50 * 3)$ tohum üzerinden tesadüf parselleri deneme planına göre yapılmıştır. Çimlenmeler 28 gün boyunca 2 gün ara ile kontrol edilmiştir. Kökçüğü en az $3 \mathrm{~mm}$ uzayan ve yere yönelim (geotropizm) gösteren tohumlar çimlenmiş olarak kabul edilmiş ve sayılarak Petri kapları içerisinden çıkarılmıştır.

\section{Tohumlarda çimlenme parametreleri}

2012 ve 2013 yılında toplanan tohumların çimlenme yüzdeleri ve ortalama çimlenme süreleri belirlenmiştir. Çimlenme yüzdesi (ÇY), Denklem 1 (Bewley vd., 2013) ile hesaplanmıştır

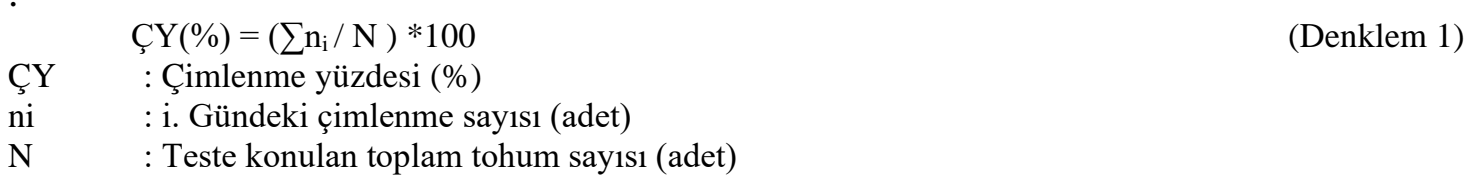

Çimlenme hızı, Ortalama Çimlenme Süresi (OÇS) formülü (Denklem 2) ile hesaplanmıştır (Bewley vd., 2013).

$$
\text { OÇS }=\left(\sum\left(\mathrm{t}_{\mathrm{i}} * \mathrm{n}_{\mathrm{i}}\right)\right) /\left(\sum \mathrm{n}_{\mathrm{i}}\right)
$$

(Denklem 2)

$\begin{array}{ll}\text { OÇS } & \text { : Ortalama çimlenme süresi (gün) } \\ \mathrm{Ti} & \text { : Testin başlangıcından itibaren geçen süre (gün) } \\ \mathrm{Ni} & \text { : t(i) gündeki çimlenen tohum sayısı (adet) }\end{array}$

Kozalak Boyutları ve A getirildikten sonra kurutma işleminden önce belirlenmiştir. Her bir popülasyondan rastgele örneklenen 50 adet kozalak üzerinde ölçümler yapılmıştır. Her bir kozalakta boy (mm) ve çap $(\mathrm{mm})$ dijital cetvel $(0.01 \mathrm{~mm}$ duyarlılıkta) ile, ă̆ırlık (gr) ise hassas terazi (0.001 duyarlılıkta) ile ölçülmüştür. 
Tohum Boyutları ve Ăğılı̆̆ı: Her bir popülasyondan rastgele alınan \%8 nem içeriğindeki (hava kurusu) 50 adet tohumda uzunluk, genişlik ve kalınlık ölçümleri yapılmıştır.

Dolu ve Boş Tohum Orant: Dolu ve boş tohum oranını belirlemek için her bir popülasyondan rastgele seçilen 150 (3x50) tohum kesilmiş ve embriyo varlığına göre dolu ve boş tohum oranı yüzde $(\%)$ olarak tespit edilmiştir.

1000-dane A Ăgrlı̆̆ı: 1000 -dane ağırlığı her bir popülasyona ait $8 * 100=800$ tohum üzerinden hesaplanmıştır. Karıştırılan tohumlardan her seferde rastgele 100 tohum alınarak hassas dijital terazide ağırlık ölçümü yapılmıştır. Aynı işlem $8 \mathrm{kez}$ tekrarlanarak bulunan ağırlık ortalamaları 10 ile çarpılmıştır (ISTA, 2018).

İstatistiksel analiz: Morfolojik verilerin ve çimlenme sonuçlarının değerlendirilmesinde varyans analizi, popülasyonlar ve farklı işlemlerin gruplandırılmasında Duncan testi kullanılmıştır. Varyans analizinde arksinüs dönüşümü yapılan çimlenme yüzdesi verileri kullanılmıştır.

\section{BULGULAR}

\section{Kozalak özellikleri}

Genel olarak kozalak boyutları (boy, çap ve ağırlık) bakımından popülasyonlar arasında farklılıklar görülmüştür (Tablo 2). 2012 y1lına ait kozalaklarda; ortalama boy $18.03 \mathrm{~mm}$, çap $10.07 \mathrm{~mm}$ ve ağırlık 0.50 gr olarak bulunmuştur. 2013 yılı kozalaklarında ise ortalama boy $17.76 \mathrm{~mm}$, çap $9.84 \mathrm{~mm}$ ve ağırlık 0.48 gr olarak ölçülmüştür. Genel ortalama olarak, en uzun boy, en geniş çap ve en ağır kozalak Türkoğlu popülasyonuna; en kısa boy, en küçük çap ve en hafif kozalak Karaisalı popülasyonuna aittir.

Tablo 2. Popülasyonların kozalak boyutları ve ağırlıkları

\begin{tabular}{lcllllllr}
\hline & Yıl & Suçatı & Türkoğlu & Andırın & Düziçi & Kozan & Karaisalı & Ortalama \\
\hline \multirow{5}{*}{ Boy $(\mathrm{mm})$} & 2012 & $17.53 \mathrm{c}^{1}$ & $21.54 \mathrm{a}$ & $17.80 \mathrm{c}$ & $16.17 \mathrm{~d}$ & $19.17 \mathrm{~b}$ & $15.95 \mathrm{~d}$ & 18.03 \\
& 2013 & $18.45 \mathrm{a}$ & $17.72 \mathrm{ab}$ & $17.86 \mathrm{a}$ & $17.83 \mathrm{a}$ & $18.12 \mathrm{a}$ & $16.58 \mathrm{ab}$ & 17.76 \\
& Ort. & $17.99 \mathrm{~B}^{2}$ & $19.63 \mathrm{~A}$ & $17.83 \mathrm{BC}$ & $17.00 \mathrm{CD}$ & $18.65 \mathrm{~B}$ & $16.27 \mathrm{D}$ & 17.89 \\
\hline \multirow{5}{*}{ Çap(mm) } & 2012 & $9.58 \mathrm{~b}$ & $12.33 \mathrm{a}$ & $9.90 \mathrm{~b}$ & $10.01 \mathrm{~b}$ & $10.13 \mathrm{~b}$ & $8.46 \mathrm{c}$ & 10.07 \\
& 2013 & $10.42 \mathrm{a}$ & $10.35 \mathrm{a}$ & $10.61 \mathrm{a}$ & $9.68 \mathrm{~b}$ & $9.04 \mathrm{c}$ & $8.91 \mathrm{c}$ & 9.84 \\
& Ort. & $10.00 \mathrm{BC}$ & $11.34 \mathrm{~A}$ & $10.26 \mathrm{~B}$ & $9.85 \mathrm{CD}$ & $9.59 \mathrm{D}$ & $8.69 \mathrm{E}$ & 9.95 \\
\hline \multirow{4}{*}{ Ağırlık(gr) } & 2012 & $0.46 \mathrm{c}$ & $0.70 \mathrm{a}$ & $0.55 \mathrm{~b}$ & $0.45 \mathrm{c}$ & $0.59 \mathrm{~b}$ & $0.23 \mathrm{~d}$ & 0.50 \\
& 2013 & $0.59 \mathrm{~d}$ & $0.51 \mathrm{bc}$ & $0.55 \mathrm{~cd}$ & $0.41 \mathrm{a}$ & $0.44 \mathrm{ab}$ & $0.39 \mathrm{a}$ & 0.48 \\
& Ort. & $0.52 \mathrm{~B}$ & $0.60 \mathrm{~A}$ & $0.55 \mathrm{~B}$ & $0.43 \mathrm{C}$ & $0.52 \mathrm{~B}$ & $0.31 \mathrm{D}$ & 0.49 \\
\hline
\end{tabular}

Aynı satır üzerinde aynı küçük harfe sahip değerler arasında istatistiksel olarak önemli bir fark yoktur ( $\mathrm{p}<0.05)$

${ }^{2}$ Aynı satır üzerinde aynı büyük harfe sahip değerler arasında istatistiksel olarak önemli bir fark yoktur $(\mathrm{p}<0.05)$.

\section{Kozalaktaki dolu ve boş tohum oranı}

2012 ve 2013 yılı tohumlarında ortalama dolu tohum oranı sirasiyla \%41.2 ve \%43.7 (genel ortalama doluluk: \%42.4) olup, benzer bir oran ortaya çıkmıştır. Dolu tohum bakımından popülasyonlar arasında ve aynı popülasyonun farklı yıllardaki tohumları arasında belirgin farklılık tespit edilmiştir (Tablo 3; Şekil 4). İki yılın ortalaması olarak en yüksek ve en düşük dolu tohum oranı Kozan (\%64.7) ve Düziçi (\%13.3) popülasyonlarında belirlenmiştir. 
Tablo 3. Popülasyonların dolu tohum oranları

\begin{tabular}{cccccccc}
\hline Toplama Yılı & Suçatı & Türkoğlu & Andırın & Düziçi & Kozan & Karaisalı & Ortalama \\
\hline 2012 & 24.0 & 37.3 & 74.7 & 18.0 & 68.0 & 25.3 & 41.2 \\
2013 & 44.0 & 46.7 & 52.0 & 8.7 & 61.3 & 49.3 & 43.7 \\
Ortalama & 34.0 & 42.0 & 63.3 & 13.3 & 64.7 & 37.3 & $\mathbf{4 2 . 4}$ \\
\hline
\end{tabular}

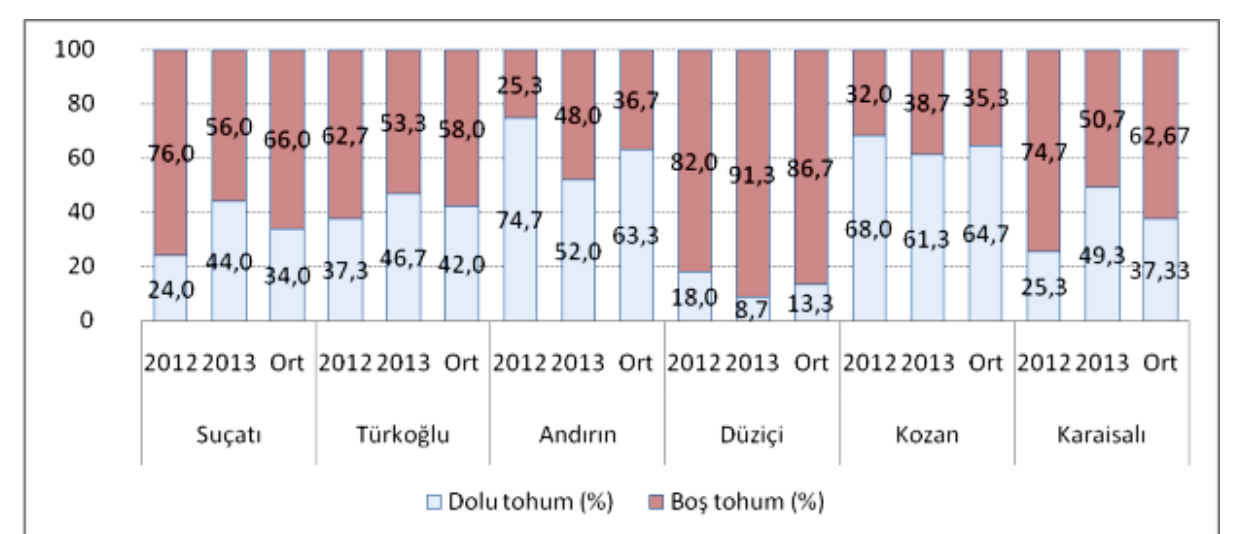

Şekil 4. Popülasyonların 2012- 2013 yıllarına ait tohumların dolu ve boş tohum oranları

\section{Tohum morfolojik özellikleri ve 1000-dane ă̆ırlı̆gı}

Tohum boyutları (en, boy ve kalınlık) bakımından popülasyonlar arasında farklılıklar görülmüştür (Tablo 4). İki yılın ortalaması olarak uzunluk $2.37 \mathrm{~mm}$, genişlik $2.68 \mathrm{~mm}$ ve kalınlık $0.74 \mathrm{~mm}$ bulunmuştur. Popülasyonlar arasında belirgin farklar mevcuttur. En uzun ve en geniş tohum Düziçi, en kalın tohum ise Kozan popülasyonuna aittir.

Tablo 4. 2012 ve 2013 y1lında toplanan tohumların boyutları

\begin{tabular}{cclllllll}
\hline & Y1l & Suçat1 & Türkoğlu & Andırın & Düziçi & Kozan & Karaisalı & Ortalama \\
\hline \multirow{3}{*}{ En $(\mathrm{mm})$} & 2012 & $2.05 \mathrm{c}^{1}$ & $2.60 \mathrm{a}$ & $2.58 \mathrm{a}$ & $2.60 \mathrm{a}$ & $2.29 \mathrm{~b}$ & $2.09 \mathrm{bc}$ & 2.37 \\
& 2013 & $2.25 \mathrm{abc}$ & $2.37 \mathrm{a}$ & $2.35 \mathrm{a}$ & $2.17 \mathrm{bc}$ & $2.28 \mathrm{ab}$ & $2.10 \mathrm{c}$ & 2.25 \\
& Ort. & $2.15 \mathrm{CD}^{2}$ & $2.49 \mathrm{~A}$ & $2.47 \mathrm{~A}$ & $2.39 \mathrm{AB}$ & $2.29 \mathrm{BC}$ & $2.10 \mathrm{D}$ & 2.31 \\
\hline \multirow{3}{*}{ Boy $(\mathrm{mm})$} & 2012 & $2.42 \mathrm{c}$ & $2.90 \mathrm{a}$ & $2.70 \mathrm{~b}$ & $2.93 \mathrm{a}$ & $2.69 \mathrm{~b}$ & $2.42 \mathrm{c}$ & 2.68 \\
& 2013 & $2.59 \mathrm{ab}$ & $2.66 \mathrm{ab}$ & $2.67 \mathrm{a}$ & $2.44 \mathrm{c}$ & $2.71 \mathrm{a}$ & $2.51 \mathrm{bc}$ & 2.60 \\
& Ort. & $2.51 \mathrm{~B}$ & $2.78 \mathrm{~A}$ & $2.69 \mathrm{~A}$ & $2.69 \mathrm{~A}$ & $2.70 \mathrm{~A}$ & $2.47 \mathrm{~B}$ & 2.64 \\
\hline \multirow{2}{*}{ Kalınlık } & 2012 & $0.65 \mathrm{c}$ & $0.74 \mathrm{~b}$ & $0.75 \mathrm{ab}$ & $0.78 \mathrm{ab}$ & $0.80 \mathrm{a}$ & $0.75 \mathrm{~b}$ & 0.75 \\
$(\mathrm{~mm})$ & 2013 & $0.74 \mathrm{~b}$ & $0.65 \mathrm{c}$ & $0.73 \mathrm{a}$ & $0.66 \mathrm{c}$ & $0.79 \mathrm{a}$ & $0.75 \mathrm{ab}$ & 0.72 \\
& Ort. & $0.70 \mathrm{C}$ & $0.70 \mathrm{C}$ & $0.74 \mathrm{~B}$ & $0.72 \mathrm{BC}$ & $0.80 \mathrm{~A}$ & $0.75 \mathrm{~B}$ & 0.73 \\
\hline
\end{tabular}

${ }_{1}^{1}$ Aynı satır üzerinde aynı küçük harfe sahip değerler arasında istatistiksel olarak önemli bir fark yoktur $(\mathrm{p}<0.05)$

${ }^{2}$ Aynı satır üzerinde aynı büyük harfe sahip ortalama değerler arasında istatistiksel olarak önemli bir fark yoktur (p<0.05).

6 popülasyonun ortalaması olarak hava kurusu durumundaki 1000-dane ağırlığı 2012 yılında $1.28 \mathrm{gr}, 2013$ yılında $1.20 \mathrm{gr}$, iki yılın genel ortalaması olarak ise $1.24 \mathrm{gr}$ bulunmuştur. Genel ortalama olarak en ağır ve en hafif popülasyon sırasıyla Andırın (1.56 gr) ve Suçatı (1.01 gr) olarak tespit edilmiştir (Tablo 5).

Tablo 5. Popülasyonların yıllara göre ortalama 1000-dane ağırlıkları

\begin{tabular}{cccccccc}
\hline & Suçatı & Türkoğlu & Andırın & Düziçi & Kozan & Karaisalı & Ortalama \\
\hline 2012 & 0.91 & 1.54 & 1.62 & 1.37 & 1.4 & 0.87 & 1.29 \\
2013 & 1.11 & 1.17 & 1.49 & 0.75 & 1.41 & 1.28 & 1.20 \\
\hline Ortalama & 1.01 & 1.36 & 1.56 & 1.06 & 1.41 & 1.08 & $\mathbf{1 . 2 4}$ \\
\hline
\end{tabular}




\section{2 yılı tohumlarının çimlenme nitelikleri}

2012 yılında toplanan tohumlarda ortalama çimlenme yüzdesi bakımından popülasyonlar arasında belirgin farklar ortaya çıkmıştır (Tablo 6). En yüksek çimlenme yüzdesi Andırın popülasyonunda elde edilmiştir. Daha sonra sırasıyla Kozan, Türkoğlu, Karaisalı, Düziçi ve Suçatı popülasyonları gelmektedir. (Şekil 5). Değişik katlama sürelerinden sonra yapılan çimlenme testlerinde 4 popülasyonda (Suçatı, Türkoğlu, Düziçi, Karaisalı) işlemler arasında önemli fark bulunmamaktadır (Tablo 6). 6 popülasyonun ortalamasına göre 8 haftalık katlama işlemi sonrasında elde edilen çimlenme yüzdesi diğer işlemlere $(0,2,4,6 \mathrm{~h})$ göre daha yüksektir. Bu belirgin yükseklikte özellikle Andırın popülasyonunun 8 haftalık katlama işleminden sonra daha yüksek çimlenme yüzdesi sergilemesi etkili olmuştur.

Tablo 6. 2012 y1lında toplanan tohumların farklı katlama sürelerinden sonra çimlenme yüzdeleri

\begin{tabular}{lcccccc}
\hline Katlama süresi & $0 \mathrm{~h}$ & $2 \mathrm{~h}$ & $4 \mathrm{~h}$ & $6 \mathrm{~h}$ & $8 \mathrm{~h}$ & Ortalama \\
\hline Suçatı & $6.7 \mathrm{a}^{1}$ & $8.0 \mathrm{a}$ & $7.3 \mathrm{a}$ & $6.0 \mathrm{a}$ & $5.3 \mathrm{a}$ & $7.0 \mathrm{E}^{3}$ \\
Türkoğlu & $16.7 \mathrm{a}$ & $13.3 \mathrm{a}$ & $14.0 \mathrm{a}$ & $13.3 \mathrm{a}$ & $14.0 \mathrm{a}$ & $14.3 \mathrm{C}$ \\
Andırın & $51.3 \mathrm{c}$ & $54.7 \mathrm{bc}$ & $55.3 \mathrm{bc}$ & $60.0 \mathrm{~b}$ & $70.0 \mathrm{a}$ & $55.3 \mathrm{~A}$ \\
Düziçi & $11.3 \mathrm{a}$ & $10.7 \mathrm{a}$ & $9.3 \mathrm{a}$ & $13.3 \mathrm{a}$ & $14.7 \mathrm{a}$ & $11.2 \mathrm{D}$ \\
Kozan & $32.0 \mathrm{~b}$ & $32.0 \mathrm{~b}$ & $30.0 \mathrm{~b}$ & $38.0 \mathrm{a}$ & $33.3 \mathrm{ab}$ & $33.0 \mathrm{~B}$ \\
Karaisalı & $9.3 \mathrm{a}$ & $11.3 \mathrm{a}$ & $12.0 \mathrm{a}$ & $14.0 \mathrm{a}$ & $13.3 \mathrm{a}$ & $11.7 \mathrm{D}$ \\
\hline Ortalama & $21.2 \mathrm{~B}^{2}$ & $21.7 \mathrm{~B}$ & $21.3 \mathrm{~B}$ & $24.1 \mathrm{AB}$ & $25.1 \mathrm{~A}$ & \\
\hline
\end{tabular}

${ }^{1}$ Aynı satır üzerinde aynı küçük harfe sahip değerler arasında istatistiksel olarak önemli bir fark yoktur $(\mathrm{p}<0.05)$

${ }^{2}$ Aynı satır üzerinde aynı büyük harfe sahip değerler arasında istatistiksel olarak önemli bir fark yoktur $(p<0.05)$.

${ }^{3}$ Aynı sütun üzerinde aynı büyük harfe sahip değerler arasında istatistiksel olarak önemli bir fark yoktur $(\mathrm{p}<0.05)$.

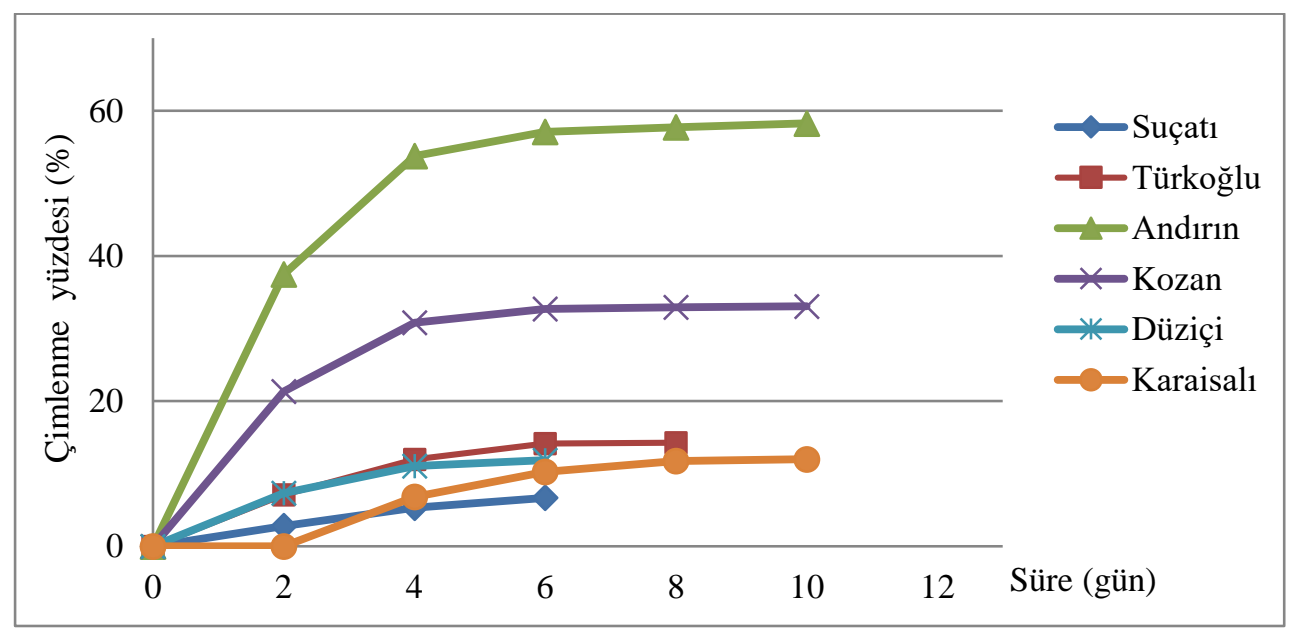

Şekil 5. 2012 y1lı tohumlarının popülasyonlara göre çimlenme yüzdeleri

A. glutinosa tohumları genel olarak oldukça hızlı çimlenmiştir (Tablo 7; Şekil 6). Popülasyonlar arasında istatistik anlamda fark olmakla beraber, bütün popülasyonlar yaklaşık 6. günde maksimum seviyelere çıkmıştır. Ortalama çimlenme süresi 3-5 gün arasında değişmektedir. Özellikle kontrol işlemi ( 0 h)'inde tohumların çimlenme hızı yavaş olup, daha uzun zamanda çimlenmiştir. 
Tablo 7. 2012 yılında toplanan tohumların farklı katlama sürelerinden sonra çimlenme hızları

\begin{tabular}{lcccccc}
\hline & $0 \mathrm{~h}$ & $2 \mathrm{~h}$ & $4 \mathrm{~h}$ & $6 \mathrm{~h}$ & $8 \mathrm{~h}$ & Ortalama \\
\hline Suçatı & $4.8 \mathrm{c}^{1}$ & $3.9 \mathrm{bc}$ & $3.0 \mathrm{ab}$ & $2.5 \mathrm{a}$ & $3.7 \mathrm{abc}$ & $3.6 \mathrm{~B}^{3}$ \\
Türkoğlu & $4.7 \mathrm{~b}$ & $3.0 \mathrm{a}$ & $3.2 \mathrm{a}$ & $2.5 \mathrm{a}$ & $3.1 \mathrm{a}$ & $3.3 \mathrm{AB}$ \\
Andırın & $4.8 \mathrm{~d}$ & $3.2 \mathrm{c}$ & $2.2 \mathrm{a}$ & $2.6 \mathrm{~b}$ & $2.3 \mathrm{a}$ & $3.0 \mathrm{~A}$ \\
Düziçi & $4.2 \mathrm{~b}$ & $2.9 \mathrm{a}$ & $2.7 \mathrm{a}$ & $2.5 \mathrm{a}$ & $2.4 \mathrm{a}$ & $2.9 \mathrm{~A}$ \\
Kozan & $4.3 \mathrm{c}$ & $3.3 \mathrm{~b}$ & $2.6 \mathrm{a}$ & $2.1 \mathrm{a}$ & $2.2 \mathrm{a}$ & $2.9 \mathrm{~A}$ \\
Karaisalı & $5.2 \mathrm{ab}$ & $5.9 \mathrm{~b}$ & $5.5 \mathrm{ab}$ & $4.9 \mathrm{a}$ & $4.8 \mathrm{a}$ & $5.2 \mathrm{C}$ \\
\hline Ortalama & $4.7 \mathrm{C}^{2}$ & $3.7 \mathrm{~B}$ & $3.2 \mathrm{AB}$ & $2.9 \mathrm{~A}$ & $3.1 \mathrm{AB}$ &
\end{tabular}

${ }^{1}$ Aynı satır üzerinde aynı küçük harfe sahip değerler arasında istatistiksel olarak önemli bir fark yoktur $(\mathrm{p}<0.05)$

${ }^{2}$ Aynı satır üzerinde aynı büyük harfe sahip değerler arasında istatistiksel olarak önemli bir fark yoktur $(\mathrm{p}<0.05)$

${ }^{3}$ Aynı sütun üzerinde aynı büyük harfe sahip değerler arasında istatistiksel olarak önemli bir fark yoktur $(\mathrm{p}<0.05)$

\section{3 yılı tohumlarının çimlenme nitelikleri}

2013 yılı tohumlarında en yüksek çimlenme yüzdesini Andırın popülasyonu sergilemiştir. Popülasyonlar arasında tohumların doluluk oranına da bağlı olarak anlamlı farklar ortaya çıkmıştır. Katlama süresi de çimlenmeleri belirgin olarak etkilemiştir (Tablo 8).

2013 yılı tohumlarında popülasyonlar arasında çimlenme hızı bakımından da farklar oluşmuştur. Doluluk yüzdesi ve dolayısıyla çimlenme yüzdesi düşük olan Düziçi popülasyonu çimlenme hızı bakımından da en sonda yer almıştır (Tablo 8).

Tablo 8. 2013 yılına ait tohumların farklı katlama sürelerinden sonra çimlenme yüzdeleri ve ortalama çimlenme hızları

\begin{tabular}{|c|c|c|c|c|c|c|c|c|c|}
\hline \multicolumn{5}{|c|}{ Çimlenme yüzdesi } & \multicolumn{5}{|c|}{ Ortalama çimlenme hızı } \\
\hline & $0 \mathrm{~h}$ & $2 \mathrm{~h}$ & $4 \mathrm{~h}$ & Ortalama & & $0 \mathrm{~h}$ & $2 \mathrm{~h}$ & $4 \mathrm{~h}$ & Ortalama \\
\hline Suçatı & $30.7 \mathrm{a}^{1}$ & $29.3 \mathrm{a}$ & $31.3 \mathrm{a}$ & $30.4 \mathrm{C}^{3}$ & Suçatı & $4.5 \mathrm{a}^{1}$ & $4.3 \mathrm{a}$ & $4.2 \mathrm{a}$ & $4.3 \mathrm{AB}^{3}$ \\
\hline Türkoğlu & $22.0 \mathrm{~b}$ & $30.0 \mathrm{a}$ & $33.3 \mathrm{a}$ & $28.4 \mathrm{C}$ & Türkoğlu & $4.3 \mathrm{~b}$ & $3.6 \mathrm{a}$ & $3.8 \mathrm{a}$ & $3.9 \mathrm{~A}$ \\
\hline Andirın & $52.7 \mathrm{~b}$ & $54.0 \mathrm{ab}$ & $60.0 \mathrm{a}$ & $55.6 \mathrm{~A}$ & Andırın & $4.5 \mathrm{~b}$ & $4.2 \mathrm{ab}$ & $3.7 \mathrm{a}$ & $4.1 \mathrm{~A}$ \\
\hline Düziçi & $2.0 \mathrm{~b}$ & $4.7 \mathrm{ab}$ & $8.0 \mathrm{a}$ & $4.9 \mathrm{D}$ & Düziçi & $8.0 \mathrm{~b}$ & $3.7 \mathrm{a}$ & $4.3 \mathrm{a}$ & $5.3 \mathrm{C}$ \\
\hline Kozan & $26.0 \mathrm{~b}$ & $39.3 \mathrm{a}$ & $44.7 \mathrm{a}$ & $36.7 \mathrm{~B}$ & Kozan & $6.4 \mathrm{~b}$ & $4.2 \mathrm{a}$ & $4.3 \mathrm{a}$ & $5.0 \mathrm{BC}$ \\
\hline Karaisalı & $19.3 \mathrm{~b}$ & $43.3 \mathrm{a}$ & $45.3 \mathrm{a}$ & $36.0 \mathrm{~B}$ & Karaisalı & $4.6 \mathrm{~b}$ & $3.9 \mathrm{a}$ & $4.0 \mathrm{ab}$ & $4.2 \mathrm{~A}$ \\
\hline Ortalama & $25.4 \mathrm{C}^{2}$ & $33.4 \mathrm{~B}$ & $37.1 \mathrm{~A}$ & & Ortalama & $5.4 \mathrm{~B}^{2}$ & $4.0 \mathrm{~A}$ & $4.1 \mathrm{~A}$ & \\
\hline
\end{tabular}

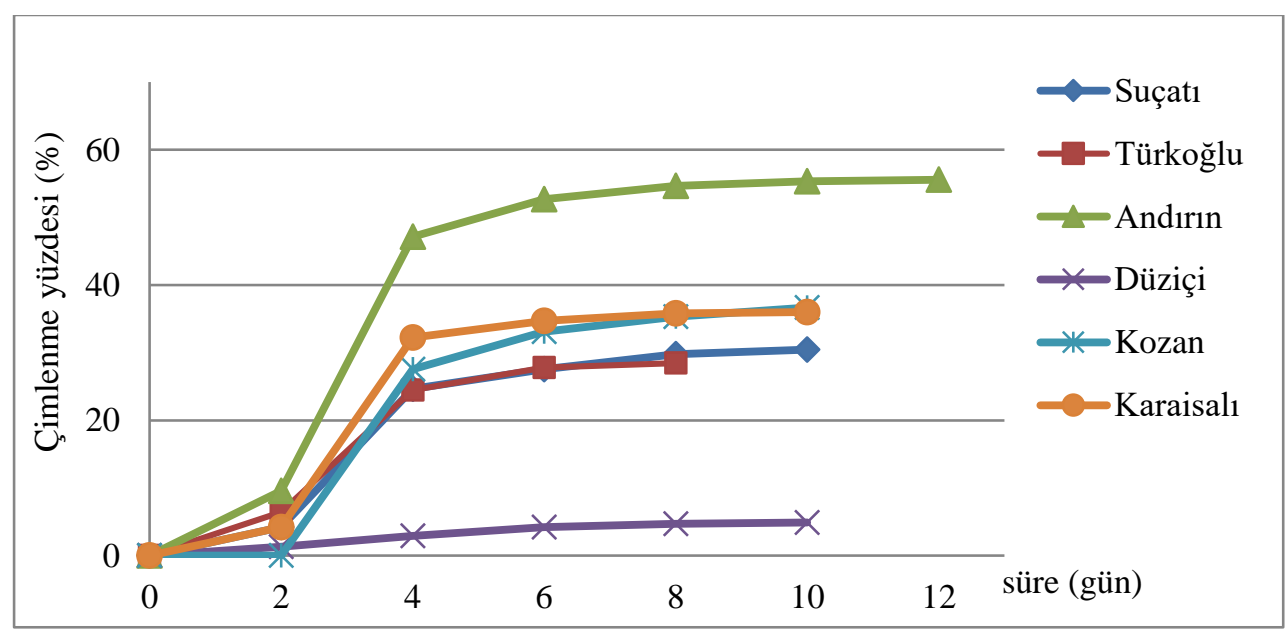

Şekil 6. 2013 y1lı tohumlarının farklı katlama sürelerinden sonraki genel ortalama çimlenme yüzdeleri 


\section{2 ve 2013 yulı tohumlarının çimlenme nitelikleri}

Relikt A. glutinosa tohumlarının genel çimlenme özelliklerini topluca görmek için 2012 ve 2013 yilı tohumlarının 0 (kontrol), 2 ve 4 haftalık katlama işlemlerinden sonraki çimlenme performansları iki yılın ortalaması olarak beraber değerlendirilmiştir.

2012 ve 2013 yılı ortalaması olarak en yüksek ve en düşük çimlenme yüzdeleri sirasıyla Andırın (\%54.7) ve Düziçi (\%7.7) popülasyonlarında ortaya çıkmıştır (Tablo 9; Şekil 7). Üç popülasyonda (Suçatı, Türkoğlu, Düziçi) katlama süresi çimlenme yüzdesini anlamlı olarak arttırmamıştır. Genel ortalama olarak 0 h (kontrol) daha düşük çimlenme sergilemiştir (Şekil 8). İki yılın ve bütün popülasyonların ortalaması olarak çimlenmelerin oldukça hızlı olduğu ve 10. günde hemen hemen tamamlandığ 1 görülmektedir (Şekil 7 ve 8).

Tablo 9. 2012-2013 yıllarına ait genel ortalama çimlenme yüzdeleri

\begin{tabular}{lllll}
\hline Popülasyonlar & $0 \mathrm{~h}$ & $2 \mathrm{~h}$ & $4 \mathrm{~h}$ & Ortalama \\
\hline Suçatı & $18.7 \mathrm{a}^{1}$ & $18.7 \mathrm{a}$ & $19.3 \mathrm{a}$ & $18.9 \mathrm{C}^{3}$ \\
Türkoğlu & $19.3 \mathrm{a}$ & $21.7 \mathrm{a}$ & $23.7 \mathrm{a}$ & $21.6 \mathrm{C}$ \\
Andırın & $52.0 \mathrm{~b}$ & $54.3 \mathrm{ab}$ & $57.7 \mathrm{a}$ & $54.7 \mathrm{~A}$ \\
Düziçi & $6.7 \mathrm{a}$ & $7.7 \mathrm{a}$ & $8.7 \mathrm{a}$ & $7.7 \mathrm{D}$ \\
Kozan & $29.0 \mathrm{~b}$ & $35.7 \mathrm{a}$ & $37.3 \mathrm{a}$ & $34.0 \mathrm{~B}$ \\
Karaisal & $14.3 \mathrm{~b}$ & $27.3 \mathrm{a}$ & $28.7 \mathrm{a}$ & $23.4 \mathrm{C}$ \\
\hline Ortalama & $23.3 \mathrm{~B}^{2}$ & $27.6 \mathrm{AB}$ & $29.2 \mathrm{~A}$ &
\end{tabular}

${ }^{1}$ Aynı satır üzerinde aynı küçük harfe sahip değerler arasında istatistiksel olarak önemli bir fark yoktur ( $\left.<<0.05\right)$

${ }^{2}$ Aynı satır üzerinde aynı büyük harfe sahip değerler arasında istatistiksel olarak önemli bir fark yoktur $(\mathrm{p}<0.05)$.

${ }^{3}$ Aynı sütun üzerinde aynı büyük harfe sahip değerler arasında istatistiksel olarak önemli bir fark yoktur $(\mathrm{p}<0.05)$.

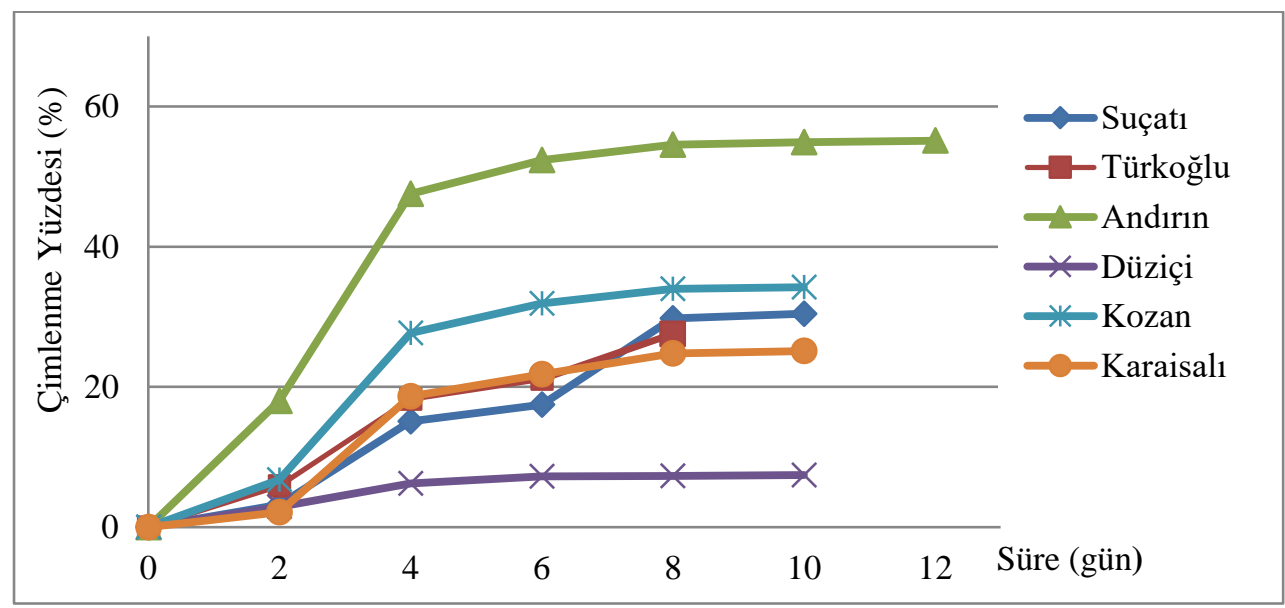

Şekil 7. 6 farklı popülasyonun iki farklı yılda toplanan tohumlarının üç farklı katlama işlemi $(0,2,4)$ sonrasındaki genel ortalama çimlenme eğrileri 


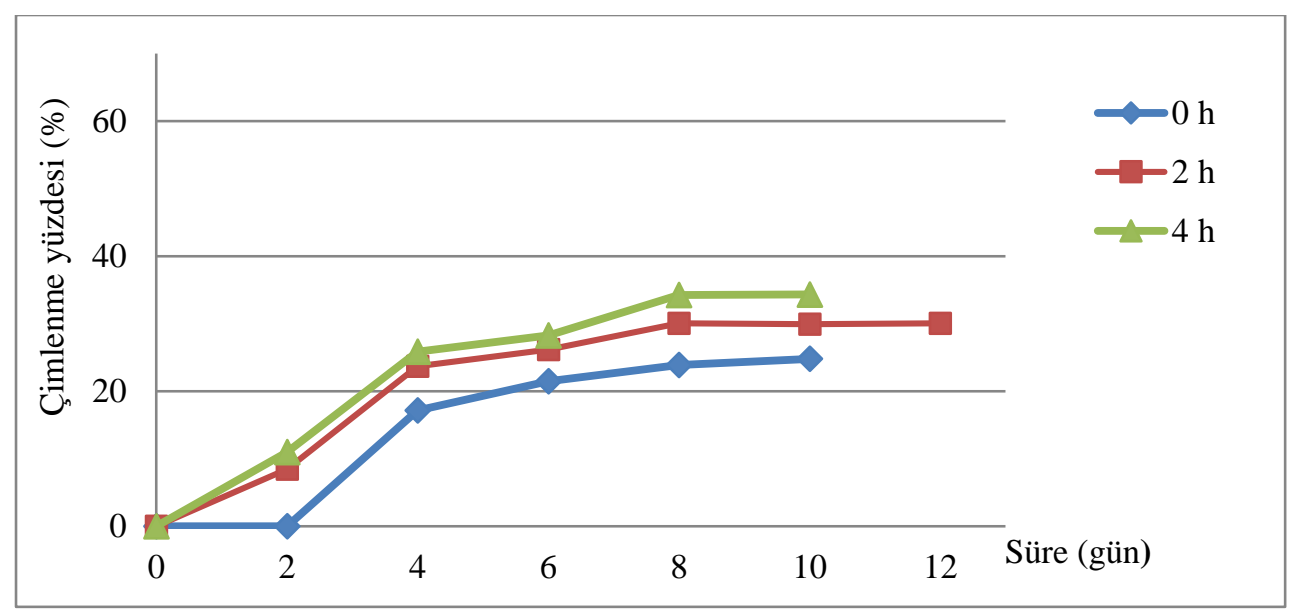

Şekil 8. 6 popülasyon ve iki farklı yıla ait tohumların genel ortalaması olarak farklı katlama sürelerinden sonra elde edilen çimlenme eğrileri

\section{TARTIŞMA VE SONUÇ}

Bu çalışmada Doğu Akdeniz de bulunan A. glutinosa türünün altı farklı popülasyonundan 2012 ve 2013 yıllarında kozalak toplanarak, kozalak ve tohum boyutları ile tohumların dormansi ve çimlenme özellikleri incelenmiştir. Ayrıca türün bölgedeki relikt popülasyonları ile ilgili devamlılık, gençleşme ve üzerindeki tehditler ile ilgili gözlemlerde bulunulmuştur.

A. glutinosa'nın kozalak ve tohumlarının morfolojik özelliklerinde popülasyonlar arasında farklılıklar gözlemlenmiştir (Tablo 2 ve 4). Tohumların şekil ve ölçülerinde popülasyonlar arasında varyasyon olması yaygın bir durum olup, (Yılmaz, 2005) genetik özellikler ve yetişme ortamı şartları tohumların şekil ve ölçülerinde belirleyici faktörlerdir (Baskin \& Baskin, 2014). 6 popülasyonun ve iki farklı yılın ortalaması olarak 1000-dane ağırlığ $1.24 \mathrm{gr}$ bulunmuştur. A. glutinosa subsp. barbata'nın 1000-tohum ağırlığı 1.12 gr'dır. Kızılağaçlar genel olarak küçük tohumlu ağaçlar olup, 1000-dane ağırlıkları 1-5 gr arasında değişmektedir (RBG Kew, 2021).

Araştırmada kullanılan kozalaklardan elde edilen tohumların \%42.4'ü doludur. 2012 ve 2013 yıllarının ortalaması olarak, Kozan popülasyonunun \%64.7'si, Düziçi popülasyonunun \%13.3'ü dolu olarak tespit edilmiştir (Tablo 3). A. glutinosa tohumlarında boş tohum oranının yüksekliği sıkça karşılaşılan bir durumdur (Berry \& Torrey 1985; Gosling vd., 2009). Bu çalışmada da genel olarak dolu tohum oranı \%50'nin altında kalmıştır (Tablo 3). Türk kızılağacı (A. orientalis) tohumlarında da 7 popülasyonun ortalaması olarak dolu tohum oranı düşük (\%47.6) bulunmuştur (Yılmaz, 2020). Kızılağaçlarda tohum verimi, türe, popülasyona ve yıla göre değişmekte olup, (Ager vd., 1994; Brown, 1986) tohum dağılımı küçük miktarlarda yıl boyunca gerçekleşir. En çok tohum dağılımı Eylül-Ekim aylarındadır (Vinther, 1983; Lewis, 1985). Tohumların toplanma zamanı kış ve bahardaki dağılım dönemlerine yakın yapıldığında tohum kalitesi ve tohum verimi artmaktadır (Lewis, 1985; Krstinic, 1994).

Relikt A. glutinosa tohumlarındaki çimlenmeler üzerinde dolu tohum oranlarının etkisi belirgindir (Tablo 9). Genel ortalama olarak en yüksek ve en düşük çimlenme yüzdesi sırasıyla Andırın (\%54.7) ve Düziçi (\%7.7) sergilemiştir. Dolu tohumların 2012 ve 2013 
yılında sırasıyla yaklaşık \%61 ve \%85'i (ortalama \%73) çimlenmiştir. Tohumların \%42.4'ü dolu olduğuna göre, boş tohumlarla beraber tohumların tamamının yaklaşık \%31'i çimlenmiştir. A. glutinosa tohumlarında embriyo ağırlığ 1 oldukça küçük olduğundan boş tohumlar yüzdürme ve savurma işlemi ile dolu tohumlardan ayrılamamaktadır. A. orientalis tohumlarında da tohumların çimlenme yüzdesi nispeten düşük gerçekleşmiş ve bu durum, tohumlardaki boş tohum oranı ile doğrudan ilintili bulunmuştur (Y1lmaz, 2020).

Bu çalışmada, A. glutinosa tohumlarına farklı sürelerde katlama uygulanmıştır ve çok hafif derinlikte uyku hali (dormansi) tespit edilmiştir. 2 ve 4 haftalık soğuk katlama işlemleri çimlenme oranlarını kısmen artırmıştır. 6 popülasyon ve 2 yılın ortalaması olarak 4 haftalık katlama işleminden sonra kontrol işlemine göre çimlenme yüzdesinde belirgin bir artış meydana gelmiştir. A. orientalis'te de benzer bir durum görülmüştür (Yılmaz, 2020). Kızılağaç tohumlarında katlama işlemi gerektirmeyen (Radwan \& DeBell, 1981) veya 2-6 haftalık kısa bir katlama işlemi ile giderilen fizyolojik dormansi bulunmaktadır (Baskin and Baskin, 2014; Harrington, 2006; Gosling, 2007; Wilson vd., 2018). Tohum dormansisi, A. rubra'da da yaygın olmasa da görülebilmektedir (Elliot \& Taylor, 1981).

Katlama işlemi uygulanmayan tohumların çimlenme yüzdesi, katlama işlemi uygulanan ve dormansisi giderilen tohumların çimlenme yüzdesine yakın gerçekleşmiştir (Tablo 9). Bundan dolayı, bölgedeki relikt popülasyonların tohumları katlama işlemi görmeden düşük rakımlardaki fidanlıklarda erken ilkbaharda ekilebilir.

Araştırma konusu relikt kızılağaçların korunması derelerdeki yaşam için önemlidir. Dere kenarlarındaki kızılağaçlar kökleri ile dere kenarlarının sağlam ve dayanıklı kalmasını sağlarlar, dereleri gölgeleyerek suyun sıcaklığını dengede tutarlar, suya dökülen bitki parçaları ile sudaki yaşamı zenginleştirirler (Claessens vd., 2010). Ayrıca dere kenarı vejetasyonlarındaki bitki örtüsü tarım alanlarından gelen azot ve fosfor gibi besin elementlerini tutarak su kalitesine katkıda bulunurlar. Mevcut relikt popülasyonlar bölgedeki akarsu kenarlarının restorasyonunda mutlaka değerlendirilmelidir. Kısmen tuzlu topraklarda da varlığını sürdürebilme özelliğinden dolayı (Deptula vd., 2020) tuzluluk olgusu bulunan denize yakın yerlerde faydalanılmalıdır.

Kızılağaçlar, Güney Anadolu'da özellikle korunması gereken bir türdür (Yılmaz, 2020). Türün bölgedeki uygun bir popülasyonu "gen koruma alanı" seçilebilir. Diğer yandan kızılağaç tohumları kurutulup uygun şartlarda yıllarca saklanabilmektedir (Suszka vd., 1996). Ex-situ koruma önlemi olarak bazı popülasyonların tohumları kurutularak soğuk ortamda depolanabilir.

Kızılağaçlar biyoenerji üretimi için değerlendirilen önemli türlerden biridir. Uzun vejetasyon dönemine sahip yöredeki relikt A. glutinosa popülasyonları biyoenerji bakımından da araştırılmalı ve değerlendirilmelidir. Kök nodülleri ile azot fiksasyonu yapan bu tür özellikle Çukurova yöresinde tarım bitkileriyle birlikte kullanılarak tarımsal ormancılık faaliyetlerinde kullanılabilir. Hızlı büyüme ve yoğun gölge yapan dekoratif görünümlerinden dolayı kentlerde nem problemi bulunmayan yerlerde dikilebilir. 


\section{KAYNAKLAR}

Ager, A.A. \& Stettler R.F. (1994) Genetics of Red Alder and its implications for future management. In: Hibbs DE, DeBell DS, Tarrant RF, eds. The biology and management of red alder. Corvallis: Oregon State University: 92-105.

Ager, A.A. Tanaka, Y. \& McGrath, J. (1994) Biology, ecology, and utilization of red alder seed. In: Hibbs DE, DeBell DS, Tarrant RF, eds. The biology and management of red alder. Corvallis: Oregon State University: 159-169.

Aksoy, N. (2014) Alnus Miller (Kızılağaçlar), (Editör) Akkemik, Ü., 2014. Türkiye'nin Doğal-Egzotik Ağaç ve Çalıları I. Orman Genel Müdürlüğü Yayınları, Ankara. s. $148-151$.

Baskin, C.C.\& Baskin, J.M. (2014) Seeds. Ecology, biogeography, and evolution of dormancy and germination. 2 ed. London: Academic Press, 1600p

Benson, D.R. \& Sylvester, W.B. (1993) Biology of Frankia strains, actinomycete symbionts of actinorhizal plants. Microbiol. Rev. 57:293-319.

Berry, A. M. \& Torrey J.G. (1985) Seed germination, seedling inoculation and establishment of Alnus spp. in containers in greenhouse trials. Plant and Soil 87(1):161-173.

Bewley, J.D., Bradford, K. \& Hilhorst, H. (2013) Seeds: Physiology of Development, Germination and Dormancy. 3 ed. New York: Springer, 408p.

Brown, S. M. (1986) Sexual allocation patterns in red alder (Alnus rubra Bong.) along three elevational transects [MS thesis]. Seattle: University of Washington, College of Forest Resources. 241s.

Claessens, H., Oosterbaan, A., Savill, P. \& Rondeux, J. (2010) A review of the characteristics of black alder (Alnus glutinosa (L.) Gaertn.) and their implications for silvicultural practices. Forestry, 83(2):163-175.

Dang, Q. L., Xie, C.Y., Ying, C. \& Guy, R. D. (1994) Genetic variation of ecophysiological traits in red alder (Alnus rubra Bong.). Canadian Journal of Forest Research 24: 2150-2156.

Deptuła, M., Piernik, A., Nienartowicz, A., Hulisz, P. \& Kaminski, D. (2020) Alnus glutinosa L. Gaertn. as potential tree for brackish and saline habitats. Global Ecology and Conservation, 22:1-11.

Elliot, D. M. \& Taylor, I. E. P. (1981) Germination of red alder (Alnus rubra) seed from several locations in its natural range. Canadian Journal of Forest Research, 11: 517521.

EUFORGEN (2021) Distribution map of black alder (Alnus glutinosa), www.euforgen.org (Erişim:Ocak, 2021).

Evans, J. (1984) Silviculture of broadleaved woodland. Forestry Commission Bulletin 62. HMSO, London.

Funk, D. T. (1990) Alnus glutinosa (L.) Gaertn. European Alder, Agriculture Handbook 654, USDA Forest Service, Washington, DC., pp.239-256.

Gillespie, A. R. \& Pope, P. E. (1994) Intensive culture of European black alder in central Indiana, U.S.A.:biomass yield and potential returns to farmers. Biomass and Bioenergy 6(6): 419-430.

Gosling, P. (2007) Raising Trees and Shrubs from Seed. Practice Guide. Forestry Commission, Edinburgh, 28p.

Gosling, P.G., Mccartan, S.A. \& Peace, A.J. (2009) Seed dormancy and germination characteristics of common alder (Alnus glutinosa L.) indicate some potential to adapt to climate change in Britain Forestry Commission Research Agency, England. p.571582. 
Harrington, C. A. (2006) Biology and ecology of red alder. Red alder; a state of knowledge. PNW-GTR-669. USDA Forest Service, Pacific Northwest Research Station, Portland, OR, 150p.

Harrington, C. A, Brodie, L. S, DeBell, D.S. \& Schopmeyer, C. S. (2008) Alnus P. Mill. The woody plant seed manual. In: Bonner FT, Karrfalt RP, eds. Agriculture handbook 727. Washington, D.C.: USDA, Forest Service.

Hibbs, D. E. \& Ager, A. A. (1989) Red alder: guidelines for seed collection, handling, and storage. Spec. Pub. 18. Corvallis: Oregon State University, Forest Research Laboratory. 6p.

ISTA (2018) International rules for seed testing, Int. Seed Testing Ass., Basserdorf, Switzerland.

Kajba, D. \& Gracan, J. (2003) Euforgen Technical Guidelines for genetic conservation and use for Black Alder (Alnus glutinosa). Int. Plant Genetic Resources Institute, Rome, Italy. $4 \mathrm{p}$.

Krstinić, A. (1994) Genetics of black alder (Alnus glutinosa). Annales Forestales, 19(2): 3372.

Kuşçuoğlu, M. \& Yılmaz, M. (2020) Güney Anadolu'daki relikt yalankoz (Pterocarya fraxinifolia (Poiret) Spach) popülasyonlarının tohum özellikleri. A ğaç ve Orman, 1(2), 44-49.

Lewis, S. J. (1985) Seedfall, germination, and early survival of red alder [MS thesis]. Seattle: University of Washington, College of Forest Resources.

McVean, D. N. (1956) Ecology of Alnus glutinosa (L.) Gaertn.: 3. Seedling establishment. Journal of Ecology 44(1): 195-218.

More, D. \& White, J. (2002) The Illustrated Encyclopedia of Trees. Timber Press Inc., Oregon, 800p.

Morene-Saiz, J.C., Dominguez, F. \& Sainez-Ollero, H. (2003) Recent progress in conservation of threatened Spanish vascular flora: A critical review. Biolological Conservation. 113: 419-431.

Özer, A. E. (2006) Dereden-Tepeden Doğal ve Yapay Alanlardaki Bitkiler, Türkiye Ormancılar Derneği, Eğitim Dizisi:3, ISBN: 975-93478-5-7, Ankara.

Radwan, M. A. \& DeBell D. S. (1981) Germination of red alder seed. USDA Res. Note: PNW-370.

RBG Kew (2021) Seed Information Database, http://data.kew.org/sid, (Erişim: Şubat, 2021).

Savill, P. (1991) The Silviculture of Trees Used in British Forestry. CAB Int., Wallingford, UK.

Schalin, I. (1967) Germination analysis of Alnus incana (L.) Moench and Alnus glutinosa (L.) Gaertn. Seeds. Oikos, 18, 253-260.

Suszka, B., Muller, C. \& Bonnet-Masimbert, M. (1996) Alnus glutinosa (L.) Gaertn. In Seeds of Forest Broadleaves from Harvest to Sowing. INRA, Paris. 294p.

Tarrant, R. F. \& Trappe, J. M. (1971) The role of Alnus in improving the forest environment. Plant and Soil, 335-348.

Vinther, E. (1983) Seedfall from Alnus glutinosa-a pioneer tree. Dansk Dendrologisk Arsskrift, 5:163-173.

White, C. M. \& West, G. C. (1977) The annual lipid cycle and feeding behavior of Alaskan redpolls. Oecologia 27: 227-238.

Wilson, S. M., Mason, B., Savill, P. \& Jinks, R. (2020) Non-native alder species (Alnus spp.), Quarterly Journal of Forestry, 112(3):163-174.

Yaltırık, F. \& Efe, A. (2000) Dendroloji Ders Kitabı. İ.Ü. Yayın No:4265/465, İstanbul. 382s. 
Yılmaz, M. \& Aslan, S. (2013) Azot bağlayarak toprağı zenginleştiren önemli bir doğal türümüz: Türk kızılağacı (Alnus orientalis Decne.), 6. Ulusal Bitki Besleme ve Gübre Kongresi Bildiriler Kitab1, 3-7 Haziran 2013, Nevşehir, s.173-174.

Yılmaz, M. (2020) Türk kızılağacı (Alnus orientalis Decne.)'nın tohum özellikleri. A ̆gaç ve Orman, 1(1), 58-65.

Yılmaz, M. (2005) Doğu kayını (Fagus orientalis Lipsky) Tohumlarının Fizyolojisi Üzerine Araştırmalar, (Doktora Tezi), İ.Ü. Orman Fakültesi, 175s.

Y1lmaz, M. (2010) Is there a future for the isolated oriental Beech (Fagus orientalis Lipsky) forests in Southern Turkey? Acta Silv. Lign. Hung., Vol. 6: 111-114.

Y1lmaz, M. (2014) New locality records and conservation of Caucasian wingnut (Pterocarya pterocarpa (Michx.) Kunth ex I.Iljınsk.) in Southern Turkey, Anadolu University Journal of Science and Technology, 3 (2):39-44.

Y1lmaz, M. \& Ekici, F. (2011) Güney Anadolu'da korunması ve değerlendirilmesi gereken önemli bir doğal ağaç türü: Doğu Kızılağacı (Alnus orientalis Decne.). K.Maraş. I. Ulusal Akdeniz Çevre ve Orman Sempozyumu, 26-29 Ekim 2011, s.325-331.

Yılmaz, M., Kaplan, A. \& Vermez Y. (2013) Kızılçam (Pinus brutia Ten)'ın üç uç populasyonuna ait bazı tohum özellikleri. KSÜ Doğa Bilimleri Dergisi, 1(16): 55-61.

Yilmaz, M. \& Ok. T. (2015) Seed characteristics of Flueggea anatolica, an endangered forest shrub species, Dendrobiology 74: 59-67. 